TAO, Vol. 16, No. 4, 775-804, October 2005

\title{
Earthquake Prediction Studies Using Radon as a Precursor in N-W Himalayas, India: A Case Study
}

\author{
Vivek Walia ${ }^{1,2, *}$, Hardev Singh Virk ${ }^{3}$, Tsanyao Frank Yang ${ }^{1}$, Sandeep Mahajan ${ }^{4}$, \\ Monika Walia ${ }^{1}$ and Bikramjit Singh Bajwa ${ }^{4}$
}

(Manuscript received 1 September 2004, in final form 20 July 2005)

\begin{abstract}
Many theoretical and empirical algorithms have been proposed in the literature for radon release; however whilst its relation with earthquake occurrence has been developed on occasions, there have been no specific complete studies of this phenomenon. In this study, radon monitoring was carried out using emanometry technique at Palampur and Dalhousie stations in the Kangra valley of Himachal Pradesh (India) from June 1996 to September 1999. Discrete radon concentrations were recorded in soil-gas and groundwater at both the stations. Radon anomalies were correlated with microseismic events recorded along the Main Boundary Thrust (MBT) of $\mathrm{N}-\mathrm{W}$ Himalaya in the grid $\left(30-34^{\circ} \mathrm{N}, 74-78^{\circ} \mathrm{E}\right)$. The influence of meteorological parameters viz. temperature, rainfall, relative humidity and wind velocity on radon concentration was qualitatively evaluated. The radon exhalation showed positive correlation with temperature, rainfall, relative humidity and negative correlation with wind velocity. Both positive and negative radon anomalies were recorded. The study reveals the precursory nature of radon anomalies and their correlation with microseismic events in $62 \%$ of the cases but prediction of earthquakes is yet a remote possibility. From the analysis it has been found that radon anomaly is not only influenced by seismic parameters but also by meteorological parameters and the nature of carrier gases/fluids. To learn more about the phenomenon, simultaneous recording of various gases $\left(\mathrm{He}, \mathrm{CO}_{2}, \mathrm{CH}_{4}\right)$ and meteorologi-
\end{abstract}

\footnotetext{
${ }^{1}$ Department of Geosciences, National Taiwan University, Taipei, Taiwan, ROC

${ }^{2}$ National Center for Research on Earthquake Engineering, Taipei, Taiwan, ROC

3 \#360, Sector 71, SAS Nagar (Mohali)-160071, India

4 Department of Physics, Guru Nanak Dev University, Amritsar-143005, India

* Corresponding author address: Dr. Vivek Walia, Department of Geosciences, National Center for Research on Earthquake Engineering, Taipei, Taiwan, ROC; E-mail:vivekwalia@rediffmail.com
} 


\title{
cal parameters, together with multiple continuous measurements of radon have been suggested.
}

\author{
(Key words: Radon, Earthquakes, Precursor, Seismo-radon algorithms)
}

\section{INTRODUCTION}

Earthquake prediction research aims to detect those variations in a number of physical parameters in a region under study, which may show some anomalous changes prior to an earthquake. These are termed as earthquake precursors. Precursors of various geophysical and geochemical natures are used in earthquake prediction. There are many published studies on geochemical precursors reporting the detection of validated precursory phenomenon between geochemical data and seismic activity. In fact, local and regional settings are important in influencing and determining the occurrence and pattern of geochemical anomalies. The accumulated information is used to investigate problems of earthquake prediction by analyzing statistical relationship of space and time characteristics of various types at different stages of earthquake preparation. A number of researchers have summed up the data of various precursors that were reported in the literature with a view to establish some regularities they have in common. Mainly, dependence of anomaly time $\Delta \mathrm{T}$ and precursor amplitude $A$ on magnitude $M$ and epicentral distance $D$ of consequent earthquakes were studied. The greatest hindrance in that sort of analysis is an insufficient record of measurement errors and the level of background noise.

Changes in subsurface radon concentration have been observed to precede earthquake occurrence and therefore radon has potential use in earthquake prediction studies. The first evidence of a correlation between radon and earthquake occurrence came from observation of radon concentration in well water prior to the Tashkent earthquake of 1966 (Ulomov and Mavashev 1967). This evidence stimulated research work in this area soon afterwards in many countries. Radon observations, both in soil-gas and in groundwater, revealed many precursory changes in its concentration before an earthquake (Talwani et al. 1980; Mogro-Campero et al. 1980; Fleischer 1981; Liu et al. 1984/85; Virk 1986, 1993, 1997; Segovia et al. 1989; King et al. 1993; Virk and Singh 1992; Igarashi et al. 1995; Heinicke et al. 1995; Virk et al. 1997; Singh et al. 1999; Chyi et al. 2005; Yang et al. 2005). Due to such observed correlation, radon is considered as one of the few promising precursors that can be used for earthquake prediction studies.

In this paper, the fundamentals of seismo-radon algorithms, proposed formulae and theoretical basis are briefly discussed along with radon monitoring results in N-W Himalayas, India. The Himalayan orogeny is believed to be a product of ongoing collision between the Indian plate with the Eurasian plate. Some of the strongest earthquakes in history have occurred in the vicinity of Himalaya as a consequence of underthrusting of the Indian plate. The Himalayan mountain range, an outcome of the compressional process ensued by the IndiaAsia collision (70 - $40 \mathrm{Ma}$ ) has been undergoing extensive crustal shortening along the entire $2400 \mathrm{~km}$ long range. A series of major thrust planes; the Main Central Thrust (MCT), the Main 
Boundary Thrust (MBT) and the Main Frontal Thrust (MFT) have been formed as a result of these processes (Gansser 1964). The evolutionary model of the Himalayas (Le Fort 1975) considers the MCT to be the older thrust plane that was more active in the early phases of the Himalayan orogeny and MBT to be the younger one that is more active currently. The steadystate model (Seeber and Armbruster 1981) treats both the MCT and MBT to be contemporaneous and merging at depths with a common detachment surface where the great Himalayan earthquakes are believed to originate. The seismicity of the Himalayas, therefore, needs to be understood in terms of the relative roles of these thrust faults.

Narula (1992) divided the main longitudinal N-W Himalayan seismic zone into discrete seismotectonic segments with well-defined transverse boundaries marked by interpretative fundamental faults. These segments are the Kashmir block, Chamba-Kishtwar block, Kangra block, Shimla block, Garhwal block and Kumaon block. Narula and Shome (1992) suggested that transverse features have a significant role in the generation and modification of some parameters. The segmentation boundaries might act as earthquake nucleation sites with rupture propagation only in one direction along the longitudinal seismic source. Macroseismic surveys conducted for earthquakes in N-W Himalaya have indicated that most of the isoseismals attenuate very rapidly in one direction resulting in an asymmetrical pattern.

Radon monitoring has been carried out at Palampur and Dalhousie stations in Kangra and Chamba valleys of N-W Himalaya using emanometry for discrete measurements of timeseries radon data since 1992. Radon data from June 1996 to September 1999 and its correlation with seismic events is a part of discussion in this paper. Both Kangra and Chamba valleys lie in the Kangra block. The Kangra valley is enclosed between the middle Siwaliks and the Dhauladhar range and the Chamba valley is enclosed between Pir Panjal and Dhauladhar ranges of Lesser Himalaya. The radon monitoring stations, as shown in Fig. 1, were chosen to be along the MBT and MCT to have maximum radon release from the deep source; Palampur being situated to the south of MBT while Dalhousie to the north side of it. Dalhousie station is situated in the vicinity, where the MBT and MCT merge into each other. Siwalik sediments contain, in general, $3-10 \mathrm{ppm}$ of uranium, which is higher than the world average of $2.1 \mathrm{ppm}$ in greywakes and $1.5 \mathrm{ppm}$ in arkoses (Wedephol 1978). The rocks present in the Palampur area are conglomerates, medium to coarse-grained sandstones with pebbles interbedded with thin clay beds. The rocks present in the Chamba area are granites, agglomeratic slate and shale.

\section{RADON EMANATION AND TRANSPORT}

Radon $\left({ }^{222} \mathrm{Rn}\right)$ is continuously generated from radium within the rock strata as an intermediate decay product of ${ }^{238} \mathrm{U}$ radioactive series. It decays with a half-life of 3.83 days and emits 5.48MeV alpha particles. Radon has 26 isotopes ranging from ${ }^{199} \mathrm{Rn}$ to ${ }^{226} \mathrm{Rn}$, three of which are naturally occurring including ${ }^{222} \mathrm{Rn}$. The other two isotopes of radon are thoron $\left({ }^{220} \mathrm{Rn}\right)$ and actinon $\left({ }^{219} \mathrm{Rn}\right)$ which belong to ${ }^{232} \mathrm{Th}$ and ${ }^{235} \mathrm{U}$ series. Due to their shorter halflives (54.55 s and $3.95 \mathrm{~s}$, respectively) their contribution to total radon emanation may be ignored. 


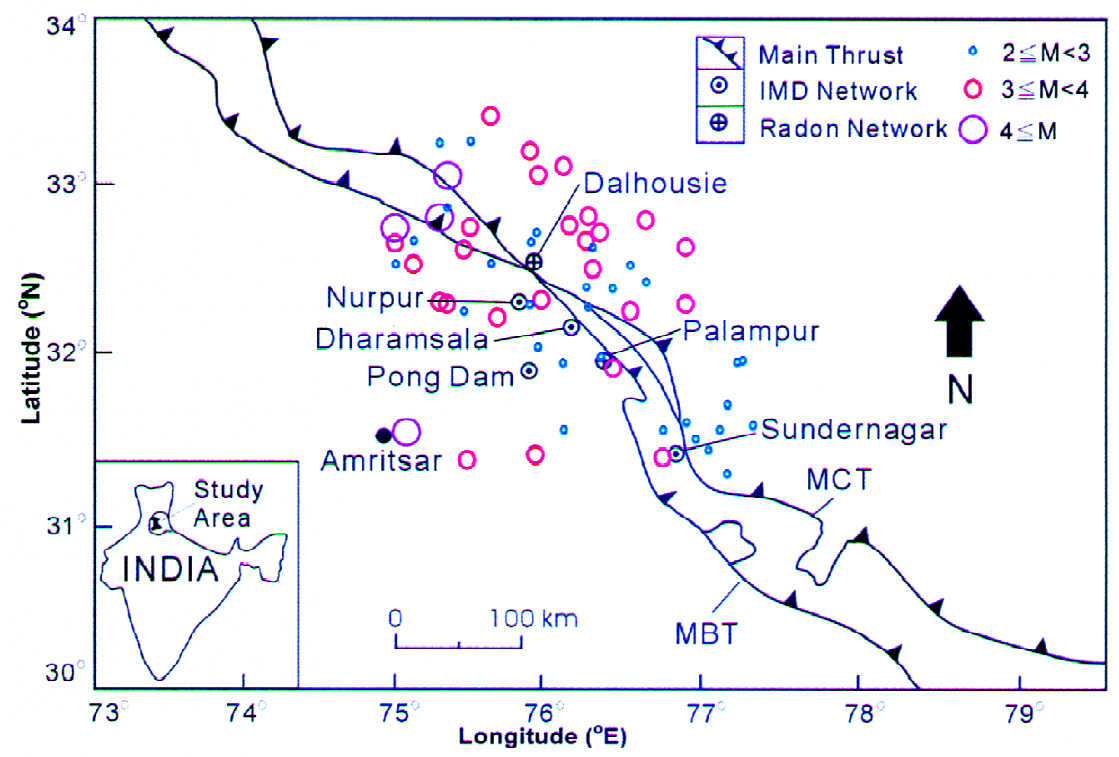

Fig. 1. Map showing radon monitoring sites (i.e., Palampur and Dalhousie) and IMD network stations (i.e., Nurpur, Dharamsala, Pong Dam and Sundernagar) along with seismic events correlated with radon anomalies in grid under reference $\left(30-34^{\circ} \mathrm{N}, 74-78^{\circ} \mathrm{E}\right)$ in N-W Himalaya.

The theory of emanation states that an isolated isotropic spherical grain of a mineral having uniform distribution of radium isotope is large enough to contain virtually all recoiling radon atoms unless the grain is less than a micron in size. The recoil energy of a radon atom is about $1 \times 10^{5} \mathrm{eV}$ and its range in a mineral grain of normal rock density will be roughly $3 \times 10^{-6} \mathrm{~cm}$. However in air, it can traverse about 2000 times more, i.e., $6 \times 10^{-3} \mathrm{~cm}$. The neutral radon atom may then diffuse and decay within the rock mass or escape from it. The fraction of the total radon atoms of the grain is therefore restricted up to the outer surface of thickness equal to the recoil range. Often a recoil atom gets lodged in the microcapillary of mineral structure. It is mostly through these capillaries filled with either an aqueous or an air medium, emanating atoms from a mineral exit. The recoil range of radon atom in water is about $1 \times 10^{-5} \mathrm{~cm}$ and two orders of magnitude less than that in air but a few multiples of its magnitude in the mineral. So radon diffusion and transport in water may proceed at a rate many orders of magnitude greater than that in the solid rocky matrix.

\section{SEISMO-RADON ALGORITHMS}

The research on seismo-radon algorithms is aimed at defining quantitative relations be- 
tween seismic parameters, such as earthquake magnitude and epicentral distance, and radon anomalies occurring in mobile systems (i.e., subsurface gas and groundwater) with endogenetic components. Such relations can be classified in two ways and will be discussed in following sections.

\subsection{Theoretical Algorithms}

Theoretically, i.e., defining an underlying theoretical physical model describing the interaction of the mechanical processes preceding an earthquake within a radon domain. Theoretical algorithms are based on the assumption that variation of radon parameters of subsurface fluids is related to changes in physical processes occurring in the lithosphere. The primary problem is that the lithosphere is an unstable and non-linear system; consequently it is very difficult to establish a definite model of interaction between rock fracturing/dislocation motion and geochemical behavior of crustal fluids.

Various theories regarding radon release and its relation with earthquake occurrence have been developed from time to time but none is complete in itself. Each theory assumes different parameters which sometimes fit into the observed data and at other times is a complete failure. Initially the Dilatancy-Diffusion Model (Scholz et al. 1973) suggested that radon anomalies are associated to mechanical crack growth rate in the volume of dilatancy or to a change in flow rate of groundwater (Fig. 2). Regarding the time of appearance or duration of precursor, it was roughly proportional to the magnitude of the earthquake, i.e., the greater the magnitude of an earthquake the larger the duration time and vice versa. The drawback with this explanation is that it often requires a huge change in stress or strain far away from the subsequent epicenter to have a considerable radon signal.

An alternative mechanism based on stress corrosion theory, which considers radon anomalies associated to slow crack growth controlled by stress corrosion in the rock matrix saturated by groundwater was given by Anderson and Grew (1977). They assumed that any mechanical cracking by stress corrosion for the crack growth should take place in a wet environment. It was confirmed by Atkinson (1979) experimentally that geological materials can suffer crack growth at very low strain rates in the presence of high humidity. The mechanism of stress corrosion suggests that occurrence of radon anomalies may depend upon strain rate and local conditions such as rock type, elastic moduli, the pattern of micro earthquakes, the degree of saturation, temperature, stress intensity factors and hydraulic properties.

A compression mechanism for radon release was proposed by King (1978). According to this mechanism the anomalous high radon concentration may be due to an increase in crustal compression before an impending earthquake that squeezes out the soil-gas into the atmosphere at an increasing rate. An increased out-gassing rate may perturb the vertical subsurface radon concentration and hence facilitate the deeper soil gas containing more radon to come up to the detection level. Hauksson (1981) suggested that radon emission in seismic zones could represent an intensity factor for a local crack system, and that radon anomalies were due to the slow growth of small cracks in the crust caused by stress corrosion by groundwater. He also suggested that radon anomalies were strongly dependent on local conditions, i.e., rock type, stress intensity factor, and degree of saturation, etc. 


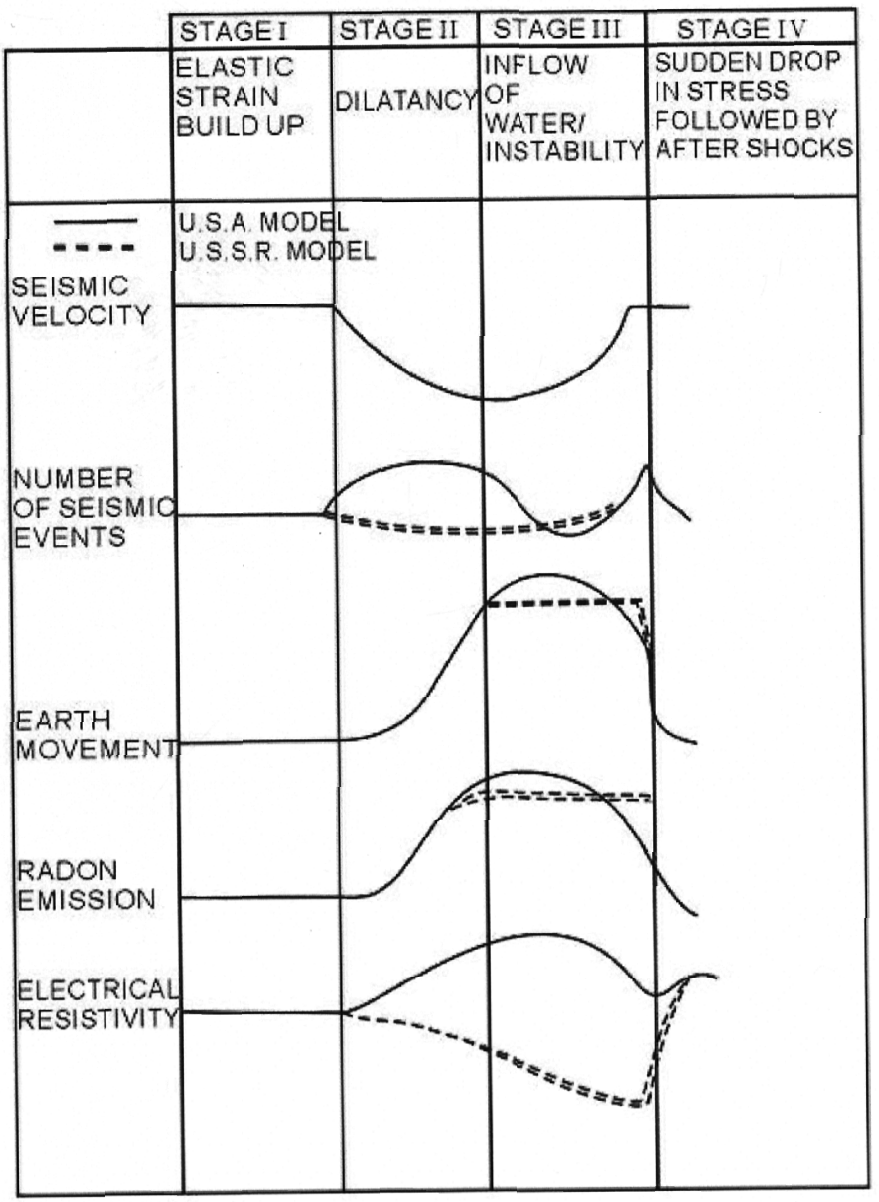

Fig. 2. Various precursory phenomena using dilatancy-diffusion model. (adopted from Scholz et al. 1973).

Presently, all the anomaly generating models are largely under debate, although most authors agree in invoking episodic crustal strain/stress field changes as the source mechanism (Fleischer 1981; King 1986). It has been observed that radon anomalies do not always precede earthquakes. While a radon anomaly may be associated with an earthquake,but the exact time of the event cannot be predicted. It has also been observed that precursor time is practically independent of the magnitude or epicentral distance of an impending earthquake (Sardarov 1981). The earthquake shock may appear while the radon is in increasing or decreasing mode. Liu et al. (1975) suggest that radon monitors located in zones of compressional strain record anomalous increase, whereas those in dilatant zones record abnormal decrease.

Due to its short half-life and insufficient diffusion length, the distance traveled by radon is limited. So, radon may be carried by other fluids or gases like $\mathrm{CH}_{4}$ and $\mathrm{CO}_{2}$ and some models 
have been proposed (Etiope and Lombardi 1995; Etiope et al. 2005). Etiope and Martinelli (2002) suggested that carrier gases like $\mathrm{CH}_{4}$ and $\mathrm{CO}_{2}$ may play an important role in controlling the migration and transport of trace gases like radon towards the surface. Based on this assumption, Yang et al. (2003) proposed radon exhalations models for some areas in southern Taiwan. More study is needed to prove these models by simultaneous recording of carrier gases $\left(\mathrm{CO}_{2}, \mathrm{CH}_{4}\right)$ together with multiple continuous measurements of radon.

\subsection{Empirical Algorithms}

Empirically, i.e., identifying patterns in radon variations that characteristically occur prior to earthquakes. Empirical algorithms are based on the statistical comparison of radon data with seismic ones, from an existing database. Attempts have been made to find mathematical relations between radon time series regarding gas and groundwater parameters and the occurrence of seismic events.

Some empirical relations have been proposed in the past relating precursor time of radon anomalies to earthquake magnitude and epicentral distance. On the basis of precursor data published up to 1977, Rikitake (1979) has given a relationship between precursor time (T) and earthquake magnitude $(\mathrm{M})$ which was obtained on the basis of the best-fitting straight line using least square method as follows:

$$
\log \mathrm{T}=0.6 \mathrm{M}-1.01
$$

Rikitake (1987) modified the relation on the basis of 14 radon data sets and based on a general linear equation $\log \mathrm{T}=\mathrm{a}+\mathrm{bM}$, as:

$$
\log \mathrm{T}=(-0.47 \pm 0.73)+(0.28 \pm 0.12) \mathrm{M}
$$

which holds well for all the precursor disciplines. Using a log-linear relationship between precursor time and earthquake magnitude, Scholz et al. (1973) established a relationship on the basis of a limited data set of radon anomalies as well as other precursors but this relationship was found to have a limited application (Hauksson, 1981).

An empirical formula relating precursor time $\mathrm{T}$ (in day) to magnitude $\mathrm{M}$ and epicentral distance D (in km) given by Sultankhodzhayev (1984), on the basis of radon data in a seismically active zone of Central Asia is:

$$
\log \mathrm{DT}=0.63 \mathrm{M}-0.15
$$

But it has been claimed that the precursor time is practically independent of the magnitude and epicentral distance of the impending earthquake (Sardorov 1981; Hauksson and Goddard 1981), therefore, predictive algorithms should not consider the precursor time.

On the basis of strain field models, Dobrovolsky et al. (1979) and Fleischer (1981) had given relations between earthquake magnitude and the radius of the effective precursory manifestation zone, where radon anomaly occurs, as follows: 


$$
\begin{aligned}
& \mathrm{D}=10 \exp 0.43 \mathrm{M}, \quad \text { (Dobrovolsky et al. } \\
& \mathrm{D}=(10 \exp 0.813 \mathrm{M}) / 1.66 \text { for } \mathrm{M}<3 \text {, and } \\
& \mathrm{D}=(10 \exp 0.480 \mathrm{M}) / 1.66 \text { for } \mathrm{M}>3, \quad \text { (Fleischer } 1981)
\end{aligned}
$$

(Dobrovolsky et al. 1979)

where, $\mathrm{D}$ is the epicentral distance in $\mathrm{km}$ and $\mathrm{M}$ is the magnitude of the earthquake on the Richter scale. According to the formulation of Dobrovolsky et al. (1979), an earthquake of magnitude 5 can be detected by means of radon precursory anomalies up to a distance of $142 \mathrm{~km}$ only, whereas experimental observations prove that earthquakes are correlatable with radon anomalies which occur at distances much greater than those calculated by the given empirical relationship.

Hauksson and Goddard (1981) proposed a modified relationship based on experimental field data for radon as:

$$
\mathrm{M}=2.4 \log \mathrm{D}-0.43 .
$$

This was used to fit worldwide radon data in groundwater for earthquakes of magnitude $\geq 5$. Taking into account the characteristics of the crustal structure in Italy and Austria, on both sides of the Alps, Friedmann (1991) further modified the above relationship as:

$$
\mathrm{M}=2.4 \log \mathrm{D}-0.43-0.4 \text {. }
$$

Virk (1996), taking recourse to the strain field models, proposed the following four relations for fitting worldwide radon data:

Epicentral distance (in $\mathrm{km}$ ), $10<\mathrm{D}<50$

$\mathrm{D}=10 \exp 0.32 \mathrm{M}$,

Epicentral distance (in km), $50<\mathrm{D}<100$

$\mathrm{D}=10 \exp 0.43 \mathrm{M}$,

Epicentral distance (in $\mathrm{km}$ ), $100<\mathrm{D}<500$

$\mathrm{D}=10 \exp 0.56 \mathrm{M}$

Epicentral distance (in km), $500<\mathrm{D}<1250$

$\mathrm{D}=10 \exp 0.63 \mathrm{M}$. 
All the above empirical relations have shown relationship between epicentral distance/ precursor time and magnitude of the seismic events but no relationship has been proposed which has correlation of amplitude of radon anomalies with a seismic event. So, the role of radon anomalies is missing in all the above relationship, therefore no relationship is universally accepted. An attempt has been made to find the relationship of radon anomalies with epicentral distance and magnitude of the seismic event using data collected in the N-W Himalayas.

\section{RADON MONITORING TECHNIQUE}

For radon monitoring in N-W Himalayas for earthquake prediction studies, two recording stations were established at Palampur and Dalhousie in Kangra and Chamba valleys of Himachal Himalayas. Radon monitoring was carried out at sites free from uranium mineralization to reduce background effects. Radon monitoring stations fall in the north-west seismic zone of India, in close proximity to MBT in the Himalayan foothills (Fig.1).

The radon concentrations in soil-gas and groundwater were measured at Palampur and Dalhousie stations along the MBT using emanometry based on scintillation technique of recording alpha particles. An emanometer (Model RMS-10) manufactured by the Atomic Minerals Division (AMD) of the Department of Atomic Energy, Hyderabad, India, was used to measure the alpha emanation rate from radon in the gas fraction of a soil or water sample by pumping the gas into a scintillation chamber using a closed-circuit technique (Fig. 3) (Ghosh and Bhalla 1966). Every time before use, the alpha detector is flushed with fresh air to minimize the background value, which is measured and later subtracted from the counted value to give a real final value of radon. This technique gives an instant value of radon concentration and is highly suitable for a quick radon survey.

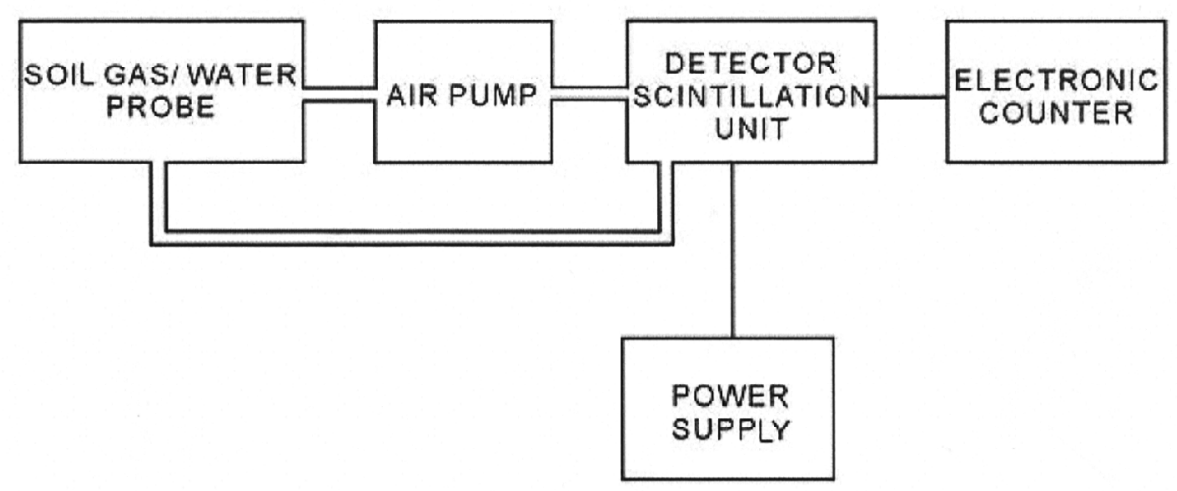

Fig. 3. Closed-circuit techniques used to measure radon activity in soil-gas and groundwater using Emanometer. 


\subsection{Radon Monitoring in Soil-gas}

For radon monitoring in soil-gas, the auger holes, each $60 \mathrm{~cm}$ in depth and $6 \mathrm{~cm}$ in diameter, are left covered for 24 hours so that the soil-gas radon and thoron become stable. The soil-gas probe is fixed in the auger hole and forms an air-tight compartment. The soil-gas probe is a $\sim 1.3$-inch diameter metallic tube with perforation at the lower portion. It has a rubber capping on the upper half of the tube, which can be inflated through one of the tubes at the top and the probe can be sealed pneumatically in an auger hole. It has out-let and inlet tubes for the circulation of the soil-gas. A hand operated rubber pump is used to circulate the soil-gas in the system. It has valves fitted on the ends and allows gas to flow in one direction only.

The rubber pump, soil-gas probe and alpha detector are connected in a closed circuit. The soil-gas is circulated through a $\mathrm{ZnS}(\mathrm{Ag})$ detector cell (i.e., Lucas-cell) $(110 \mathrm{ml})$ for a period of 10 minutes till the radon forms a uniform mixture with air (Fig. 4). The detector is then isolated by clamping both the ends and observations are recorded after 4 hours when equilibrium is established between radon and its daughters. Alpha particles emitted by radon and its daughters are recorded by the scintillation assembly consisting of a photomultiplier tube and a scalar-counter unit.

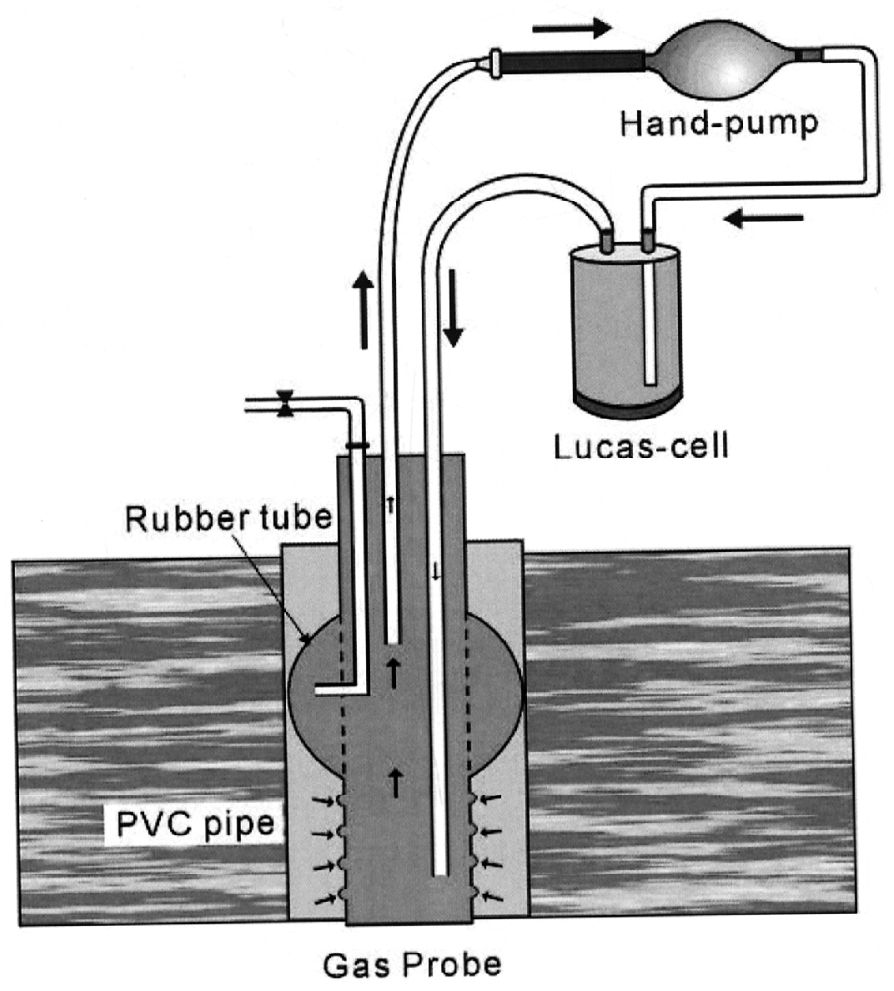

Fig. 4. Sketch for soil-gas radon sampling. 


\subsection{Radon Monitoring in Groundwater}

Radon monitoring in water is also carried out using closed-circuit technique. Groundwater samples were collected daily from a 'bauli' (natural spring) in a 250-ml sample bottle. The air is circulated in the closed-circuit containing a hand-operated rubber pump, the water sample bottle, a drying chamber (U-shaped glass tube containing fused calcium chloride) and a $\mathrm{ZnS}$ (Ag) detector cell (i.e., Lucas-cell) for 10 minutes (Fig. 5). The alpha counts are recorded after four hours during which the secular equilibrium between radon and its daughters is established.

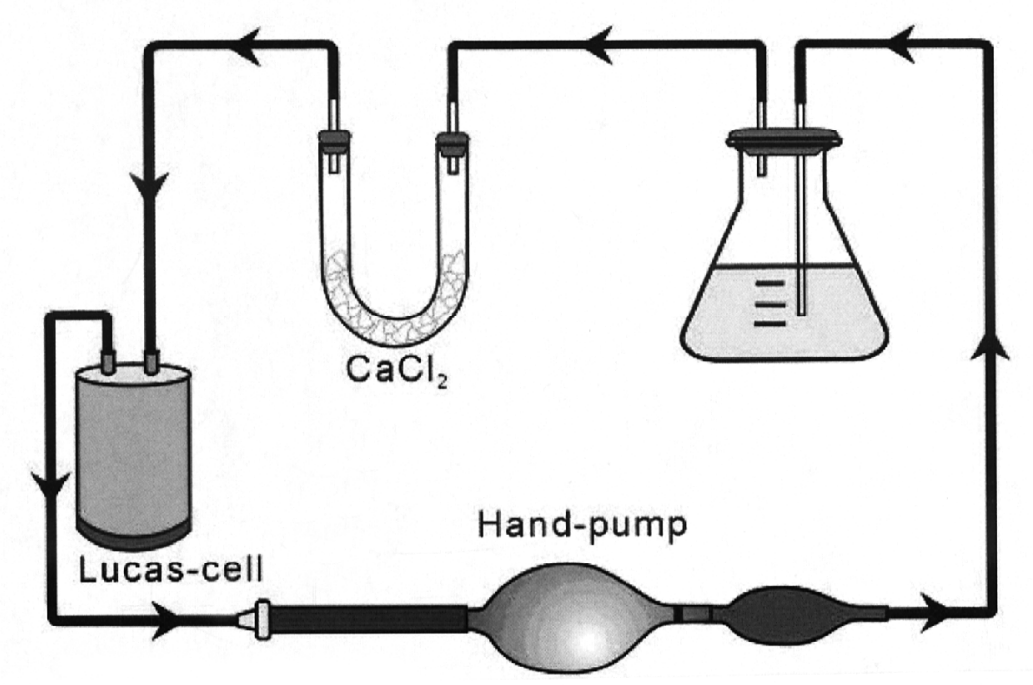

Fig. 5. Sketch for groundwater radon sampling.

\section{RADON MONITORING RESULTS}

Radon concentrations in soil-gas and groundwater have been monitored daily at Palampur and Dalhousie stations since 1992 using radon emanometry. Radon concentration is monitored in a discrete mode at mid-day along with meteorological variables in the campus of Himachal Pradesh Krishi Vishvavidalya at Palampur while this facility is restricted to only radon measurements at Dalhousie station. It is assumed that the weather conditions are almost identical in the environs of radon monitoring stations irrespective of their locations, Palampur being situated in the south of MBT while Dalhousie on the north side (Fig. 1).

\subsection{Correlation of Radon Emanation with Meteorological Parameters}

There are a number of variables other than seismic events that influence radon emanation from earth's surface at a given location. The most important factor is influence of meteorological parameters, viz. temperature, pressure, wind velocity, rainfall, and humidity. Influence 
of meteorological parameters on radon exhalation has been previously reported by various authors (Kraner et al. 1964; Pearson 1967; Gabelman 1972; Steele 1981; Singh et al. 1988; Singh and Virk 1994; King and Minissale 1994; Sharma et al. 2000; Virk et al. 2000; Mukherji et al. 2001).

The effect of meteorological variables on radon concentration in soil-gas at Palampur is taken into consideration. As already established (Virk and Singh 1992; Sharma et al. 2000; Virk et al. 2000) for N-W Himalaya, the temperature, rainfall and relative humidity have positive correlation with radon concentration while wind velocity shows a negative correlation. Correlation coefficients of radon exhalation in soil with different meteorological parameters are summarized in Table 1. However, the data on pressure variation was not available. Radon data in soil-gas, collected from Palampur and Dalhousie have been plotted taking average season values and as shown in Fig. 6.

Radon values are found to be maximum in the months of July to September, i.e., the summer rainy season when the values of relative humidity, temperature and rainfall are maximum (Fig. 6). Minimum values of radon are observed in the winter season, i.e., November to January when the temperature values are also minimum. The radon values start rising from February and reach the maximum in the month of July. In the months of May \& June, radon shows a decrease. The average value of radon for soil-gas at Palampur is reported to be $22 \mathrm{kBq} \mathrm{m}^{-3}$ with a standard deviation (Std) of $12.7 \mathrm{kBq} \mathrm{m}^{-3}$. The percentage variation coefficient (Std/Avg) of radon is $58 \%$ (Table 1). The influence of meteorological parameters on radon emanation is described in following sections.

\subsubsection{Soil Temperature}

Radon values show similar trend with the soil temperature; as the soil temperature rises, the radon values also increase. The radon value is maximum in the summer rainy season (July to September) when the temperature is also on the higher side, whereas minimum values were recorded in the winter season, i.e., in the months of November to January when the tempera-

Table 1. Correlation coefficient of radon concentration in soil-gas with different meteorological parameters at Palampur.

\begin{tabular}{lcccc}
\hline Parameter & $\begin{array}{c}\text { Average } \\
\text { (Avg) }\end{array}$ & $\begin{array}{c}\text { Standard } \\
\text { Deviation } \\
(\text { Std })\end{array}$ & $\begin{array}{c}\text { \% Variation } \\
\text { Coefficient } \\
\text { (Std/Avg) }\end{array}$ & $\begin{array}{c}\text { Correlation } \\
\text { Coefficient }\end{array}$ \\
\hline Radon $(\mathrm{Bq} / \mathrm{L})$ & 22 & 12.7 & 58 & -- \\
Temperature $\left({ }^{\circ} \mathrm{C}\right)$ & 23.9 & 5.4 & 23 & 0.18 \\
Relative Humidity $(\%)$ & 64.3 & 18.1 & 28 & 0.31 \\
Rainfall $(\mathrm{mm})$ & 5.5 & 14.8 & 267 & 0.19 \\
Wind Velocity $(\mathrm{km} / \mathrm{hr})$ & 4.5 & 1.4 & 32 & -0.27 \\
\hline
\end{tabular}




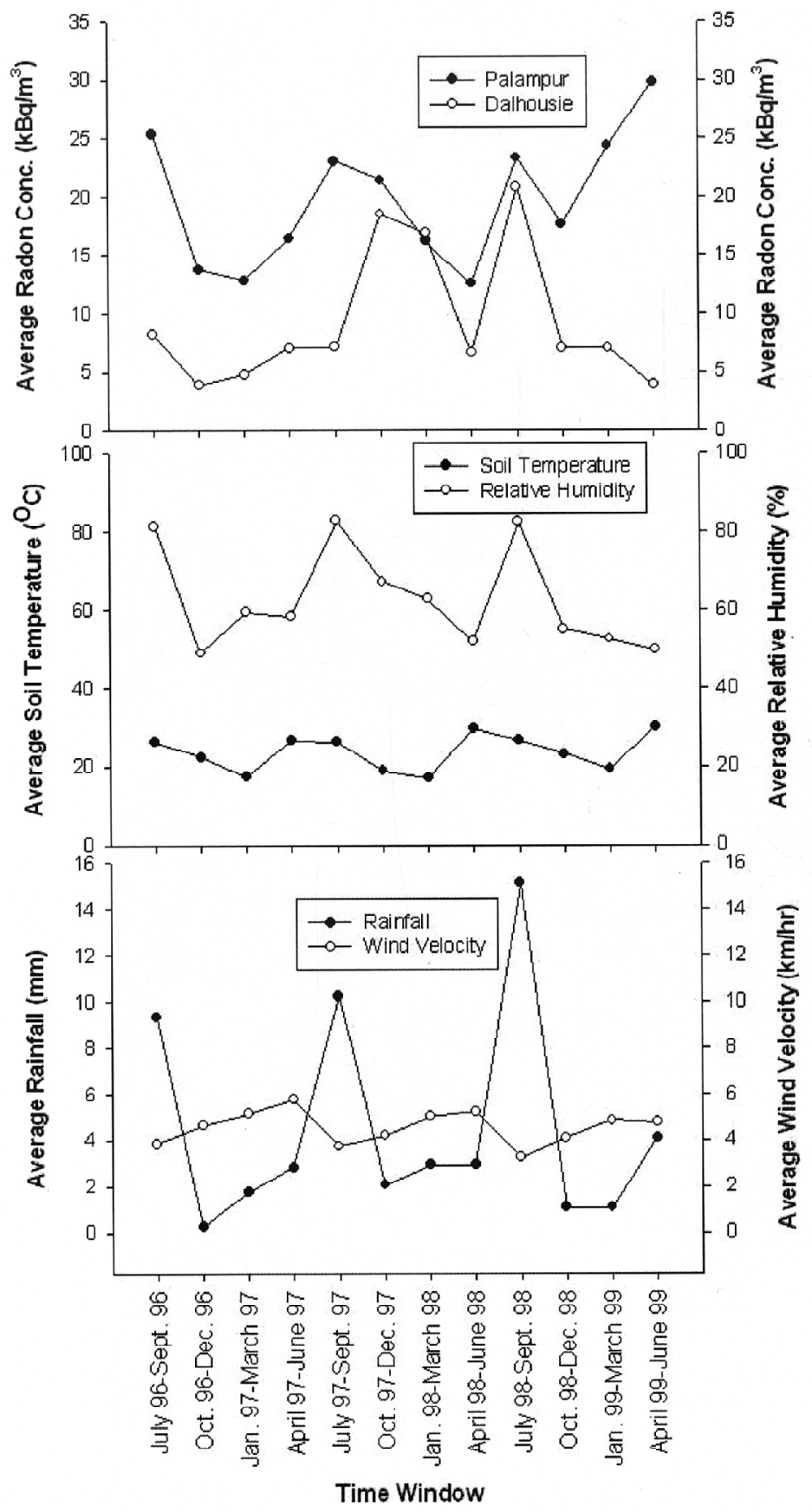

Fig. 6. Seasonal variation of soil-gas radon concentration at Palampur and Dalhousie along with soil temperature, relative humidity, rainfall and wind velocity. 
ture is on the lower side (Fig. 6). The soil temperature is found to have positive correlation with radon exhalation, and correlation coefficient is 0.18 (Table 1). The average value of temperature for the given time window was $23.9^{\circ} \mathrm{C}$ with a standard deviation of $5.4^{\circ} \mathrm{C}$ and percentage variation coefficient of $23 \%$. An increase in surface temperature causes the soilgas radon to expand and escape, and also tends to release the vapour adsorbed to the surface of the soil particles. The low value of correlation coefficient indicates that radon concentration is less affected by the change in soil temperature (Ball et al. 1983; Lindmark and Rosen 1985).

\subsubsection{Relative Humidity}

From Fig. 6, it is clear that radon values show similar trend with the relative humidity; i. e., with an increase in relative humidity the radon values increase. The radon value was found to be maximum in the summer rainy season (July to September) when the relative humidity is also highest, whereas it is minimum in winter, i.e., in the months of November to January when the temperature is on the lower side (Fig. 6). The relative humidity is found to be minimum in the months of May-June, i.e., summer, and radon values show a dip in this period although the temperature values are high. The average value of relative humidity was $64.3 \%$ with a standard deviation of $18 \%$ and a percentage variation coefficient of $28 \%$. High temperature and increase in relative humidity enhance radon exhalation. The relative humidity has positive correlation with radon exhalation and the value of correlation coefficient is found to be 0.31 (Table 1), showing that humidity influences radon exhalation more than the soil temperature. Soil-moisture has a major impact on observed soil-gas radon concentration and the radon exhalation increases with an increase in soil-moisture (Baranov and Novitskaya 1960; Damkjaer and Korsbech 1985; Lindmark and Rosen 1985). Water is the most important agent in enabling radon to escape from the solid material, because the water surrounding the soil particles absorbs the kinetic energy of the radon atom's recoil and prevents the radon atom from burying itself in an adjacent soil grain (Tanner 1980).

\subsubsection{Rainfall}

Radon values are generally found to increase in mild rain. When there is a heavy rain, the radon value initially falls and then starts rising over a period of time. This increase may be due to the capping effect of wet soil layers at the surface which prevents radon from escaping into the atmosphere (Kraner et al. 1964; Jaacks 1984; Hesselbom 1985; Singh et al. 1988; Virk et al. 2000). The radon values are high in the summer rainy season, i.e., July to September. The rainfall is positively correlated with radon concentration and the correlation coefficient is found to be 0.19 (Table 1). The average value of rainfall was found to be $5.5 \mathrm{~mm}$ with a standard deviation of $14.8 \mathrm{~mm}$ while the percentage variation coefficient was found to be very high, i.e., $267 \%$.

\subsubsection{Wind Velocity}

Gusting winds cause a decrease in soil-gas radon concentration because soil-gas is being 
diluted or removed at the surface (Kraner et al. 1964; Miller and Ostle 1973; Jaacks 1984; Hesselbom 1985; Lindmark and Rosen 1985; Singh et al. 1988; Virk et al. 2000). Radon values show a dip in the months of May-June, although the temperature values are high, which may be due to high wind velocity and low relative humidity (Fig. 6). Wind velocity was found to have an inverse correlation with radon exhalation with a correlation coefficient of -0.27 (Table 1). The average value of wind velocity was found to be $4.5 \mathrm{~km} \mathrm{hr}^{-1}$ with a standard deviation of $1.4 \mathrm{~km} \mathrm{hr}^{-1}$ and percentage variation coefficient of $32 \%$.

In general, the meteorological parameters do not have a predominant effect on diurnal variations of radon concentration in soil-gas if emanometry data are recorded in deep boreholes. The correlation of radon data with meteorological parameters (Table 1) reflects that radon emanation in soil-gas is affected to a considerable extent, which can not be ignored for all practical purposes. Radon exhalation generally rises during the summer months accompanied by the rainy season and shows a low in winter. Apart from meteorological variations radon migration depends on the geology and geotectonics of the area, the underlying rock strata, porosity and permeability of the crustal rocks and soil through which it is emanating.

\subsection{Correlation of Radon Emanation with Seismic Events}

Radon anomaly is defined, as a matter of convention, as any sudden change in radon concentration crossing the average of that season by $\pm 2 \sigma$, where $\sigma$ represents the standard deviation from the mean value $\bar{X}$. Radon anomalies crossing $\bar{X}+2 \sigma$ are called positive anomalies and those crossing $\bar{X}-2 \sigma$ are called negative anomalies. Generally, radon anomalies precede the seismic events and are called pre-seismic or precursory anomalies. Sometimes, these occur simultaneously with seismic events and are classified as co-seismic. However, it is also observed that some anomalies follow the seismic events, which seems a bit strange, as these are not helpful in earthquake prediction studies. In case of major earthquakes, several anomalies precede the seismic event but in case of micro earthquakes only one or two anomalies are recorded. Precursor time is generally defined as the interval between the time of recording of radon anomaly and the occurrence of the seismic event in the grid under reference. For major events, it can vary from a week to several months but in case of micro earthquakes it may vary from a few minutes to a few days. All other parameters, viz. magnitude, depth, epicentral distance, latitude and longitude of the seismic events are calculated following the standard procedure laid down in seismology.

Radon anomalies, the frequency of occurrence, the precursor time interval and peak amplitude can be correlated with earthquake data, such as, the respective magnitudes and epicentral distances. In general, radon anomalies occur at greater epicentral distances for earthquakes of larger magnitudes. These distances are larger than several times the rupture dimensions of the future earthquakes. The time from the onset of an anomaly to the time of the earthquake occurrence (the precursor time) increases with magnitude but decreases with distance between the epicenter and radon monitoring station. In addition, radon anomalies are observed more frequently prior to earthquakes of large magnitude than to earthquakes of small magnitude; indicating that the preparation zone increases in size as magnitude increases. In case of micro earthquakes, anomalies are not frequent; rather, they follow a random trend. The peak ampli- 
tude does not scale with magnitude but form a consistent pattern with epicentral distance such that the larger the earthquake magnitude, the farther away the largest amplitude tends to occur.

Radon emanometry data in the grid $\left(30-34^{\circ} \mathrm{N}, 74-78^{\circ} \mathrm{E}\right)$ for the time-window June 1996 to September 1999 for Palampur and Dalhousie stations are plotted (Figs. 7 - 10). There are large-scale fluctuations in the time-series radon data but the general trend is similar to previous years (Virk and Sharma, 1997). Radon emanation in soil-gas is enhanced generally after heavy rainfall in the months of July and August (monsoon season in N-W Himalaya). This trend is not observed in groundwater because meteorological variables do not influence radon concentration to the same extent as in the soil-gas. However, during winter months of December 1997-January 1998, unusual radon behavior is observed in the soil-gas both at Palampur and Dalhousie stations. Five radon anomalies are observed during December 1997 showing a rise in seismic activity and the occurrence of five micro earthquakes along the MBT. This anomalous behavior is not reflected in groundwater radon. The highest radon concentration is observed in soil-gas at Palampur during July-August 1999 during and after the monsoon rains. This behavior is absent at Dalhousie station. On the contrary, radon highs are observed in groundwater during the rainy season and afterwards at Dalhousie. The lowest value of $0.56 \pm 0.14 \mathrm{kBq} \mathrm{m}^{-3}$ in soil-gas was recorded at Palampur on 19 February, 1998 whereas in groundwater lowest value of $4.55 \pm 0.39 \mathrm{~Bq} \mathrm{~L}^{-1}$ was recorded on 23 August, 1997. At Dalhousie station the lowest value of $0.59 \pm 0.14 \mathrm{kBq} \mathrm{m}^{-3}$ and $1.48 \pm 0.22 \mathrm{~Bq} \mathrm{~L}^{-1}$ were recorded in soilgas and groundwater on 4 October, 1996 and 26 December, 1996, respectively. In general, the percentage error is less than $25 \%$ for both the stations in both the media.

Radon concentration at a station depends upon various geological, geophysical and meteorological factors. It also depends upon the nature of the soil, its porosity and permeability and presence of radioactive minerals. Site selection is a major problem in N-W Himalaya. The tectonic uplift and the relative motion of crustal blocks along the MBT influences radon emanation under seismic strain build up uniquely at Palampur and Dalhousie stations. Hence, there is no one to one correspondence between radon anomalies recorded at both the stations and in both the media. Average radon concentration during the time-window June 1996 to September 1999 in groundwater and soil-gas at Palampur is $57 \mathrm{~Bq} \mathrm{~L}^{-1}$ and $22 \mathrm{kBq} \mathrm{m}^{-3}$, respectively. Whereas, at Dalhousie station the average value of radon concentration in groundwater and soil-gas is $4 \mathrm{~Bq} \mathrm{~L}^{-1}$ and $9 \mathrm{kBq} \mathrm{m}^{-3}$. The average values of radon concentration at Palampur are much higher than Dalhousie in both media. It clearly shows that the transport mechanism of radon is different for both Palampur and Dalhousie stations, which is influenced by the characteristic of the basement rocks.

Correlation of radon anomalies recorded in soil-gas and groundwater with seismic events recorded (Fig. 1) in the grid under reference $\left(30-34^{\circ} \mathrm{N}, 74-78^{\circ} \mathrm{E}\right)$ are summarized in Table 2. The total number of microseismic events correlated are sixty-three and their magnitudes vary from $2.1-4.8$ on the Richter scale with the exception of Chamoli earthquake $\left(6.8 \mathrm{M}_{\mathrm{b}}\right)$ which occurred outside the grid but recorded its signature at Palampur station (Virk et al. 2001). Almost all the micro earthquakes correlated with radon anomalies are in the grid $\left(30-34^{\circ} \mathrm{N}\right.$, $74-78^{\circ} \mathrm{E}$ ) having epicentral distances less than $200 \mathrm{~km}$. Chamoli earthquake epicenter was $393 \mathrm{~km}$ from the Palampur radon observatory. Himalayan earthquakes have shallow depths of foci and are confined to the Main Boundary Thrust. 
The maximum number of radon anomalies, i.e., thirty-six, were recorded in soil-gas at Palampur and out of these, twenty-one anomalies were correlated with twenty-six seismic events (Fig.7). Four anomalies were followed by more than one earthquake, e.g., radon anomaly on 24 December, 1997 was followed by two earthquakes that occurred on 24 and 25 December, 1997 of magnitudes 2.5 and 2.2, respectively, at epicentral distances of $49 \mathrm{~km}$ and $60 \mathrm{~km}$ from the radon observatory. Similarly, radon anomaly on 30 June, 1998 was followed by three events of magnitude 3.5, 4.1 and 3.0, respectively, on 1, 5 and 6 July, 1998. Radon anomaly on 27 March 1999 was not only followed by a major seismic event of magnitude 6.8, recorded as Chamoli earthquake on 29 March, but also by a seismic event of magnitude 3.0 on $30 \mathrm{March}$, having epicentral distance of $17 \mathrm{~km}$ only. Also the radon anomaly on 27 July, 1999 was followed by two seismic events of magnitude 3.2 and 3.0 respectively on 27 and 28 July, 1999 (Table 2). Out of four negative anomalies recorded in soil-gas at Palampur only two were correlated with the seismic events. Both these correlated anomalies were observed within a span of 4 days only.

Radon anomalies recorded in groundwater at Palampur are shown in Fig. 8. Twenty-six radon anomalies were recorded and out of these, eighteen anomalies have been correlated with twenty-three seismic events (Table 2). Four anomalies were followed by more than one seismic event. Fourteen negative anomalies, which are unusually high numbers for any given station, were recorded.

Radon anomalies recorded in soil-gas at Dalhousie are shown in Fig. 9. Nineteen radon anomalies out of twenty-nine recorded were correlatable with twenty-four seismic events (Table 2). Three anomalies were followed by more than one seismic event. The radon anomaly on 24 February, 1999 was correlated with four seismic events: one post-seismic, one co-seismic and two preseismic with a precursor time of 4 days. It is the maximum number of events correlated with a single anomaly in the whole data set (Table 2). Five negative anomalies were recorded and correlated with four seismic events.

Radon anomalies recorded in groundwater at Dalhousie are shown in Fig. 10. Twentyfive radon anomalies were recorded and out of these, fifteen are correlatable with fifteen seismic events (Table 2). Three anomalies were followed by more than one seismic events. Four negative anomalies have been correlated with two seismic events.

Palampur station is found to be relatively more sensitive than the Dalhousie station as a total number of forty seismic events correlated with radon anomalies were observed at Palampur as compared to thirty-six events at Dalhousie in both the media. Also a maximum number (thirty-six) of radon anomalies in soil-gas were observed at Palampur. A total of 126 radon anomalies were observed in the whole grid during the given time window and out of it, seventy-four are correlated with seismic events. Most of the anomalies are pre-seismic (76\%) whereas only $14 \%$ are co-seismic and $10 \%$ are post-seismic. Critical analysis of each station reveals that groundwater at Palampur has shown the highest confidence level of 2.23 (Table. 3), which is defined as the ratio of signal to noise. A signal is further defined as the ratio of correlated anomalies to the total anomalies whereas noise is the ratio of uncorrelated anomalies to total anomalies.

The eight radon anomalies observed during December 1997 - January 1998 in soil-gas at Palampur clearly establish the correlation of radon with microseimic activity in N-W Himalaya. 


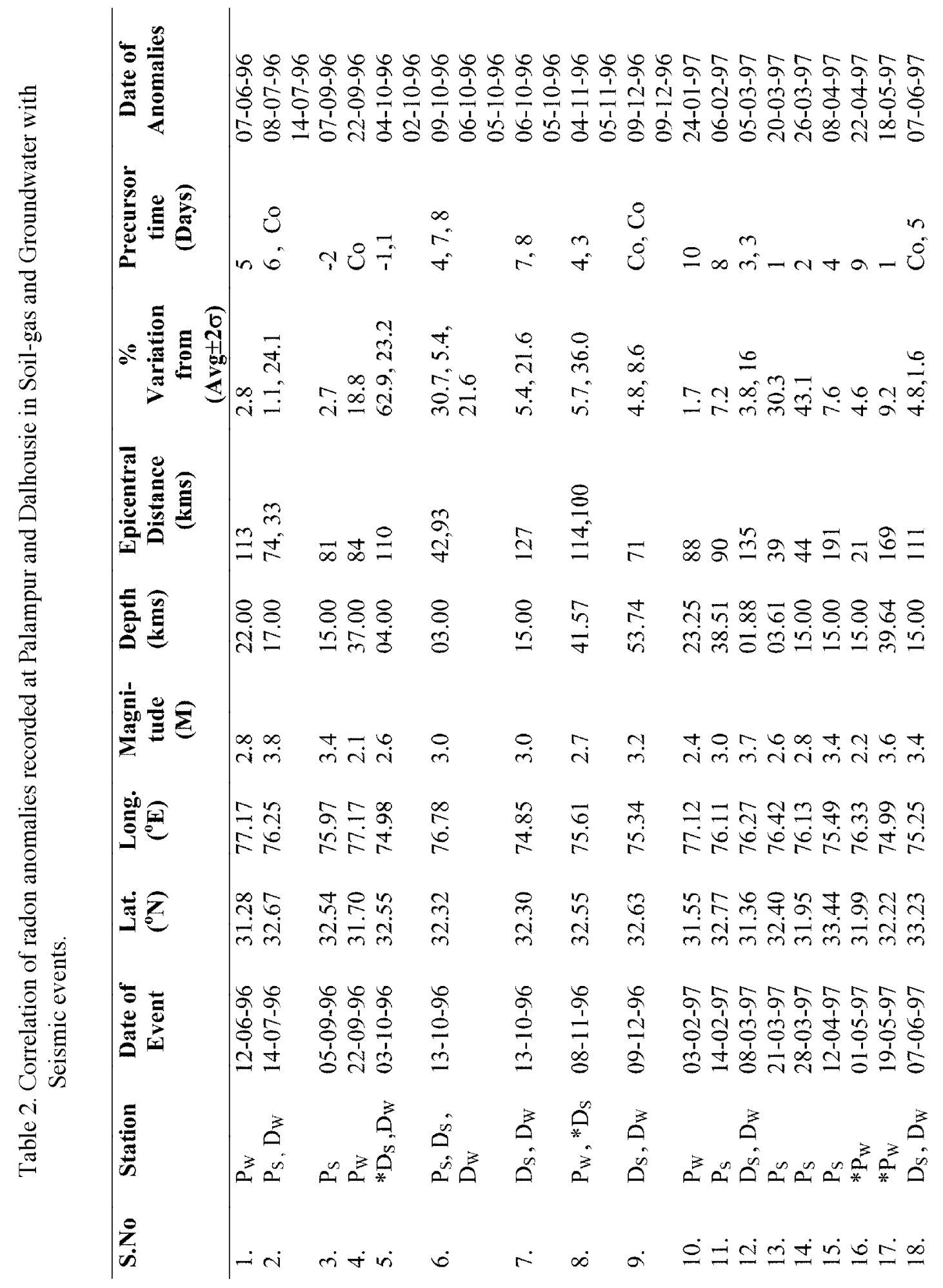




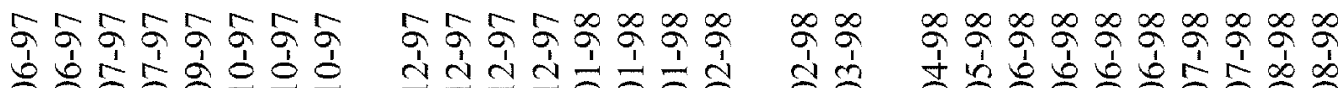

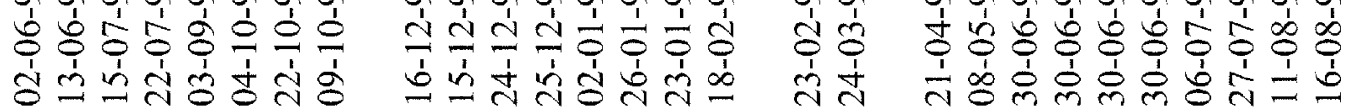

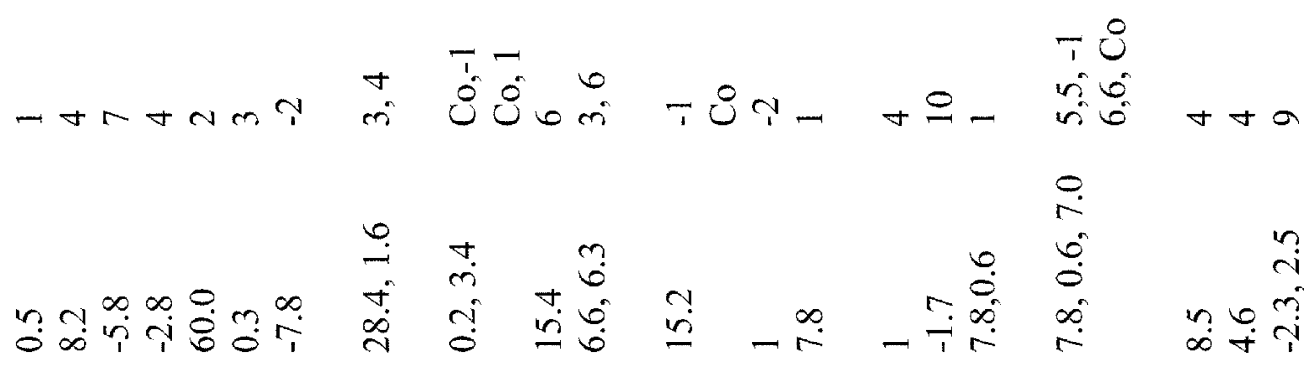

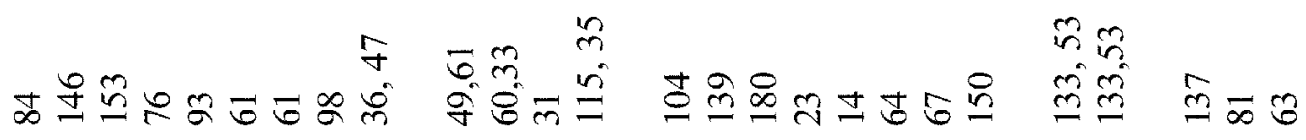
8ณ

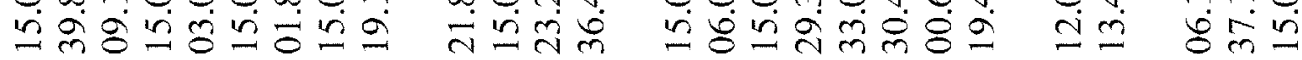

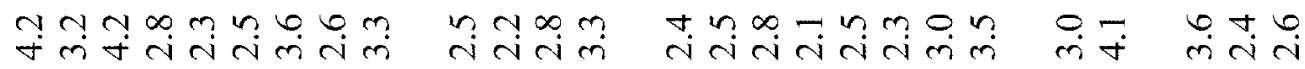

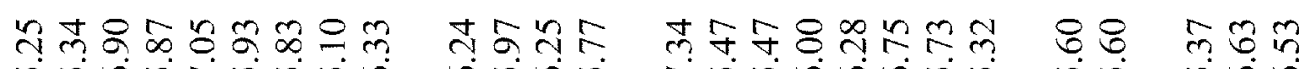

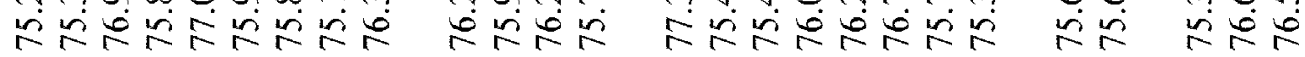

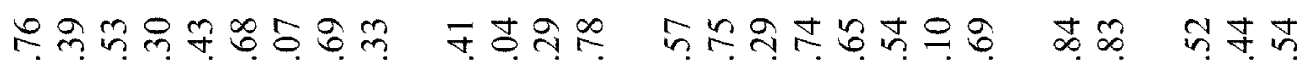

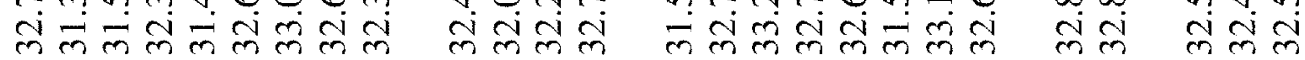

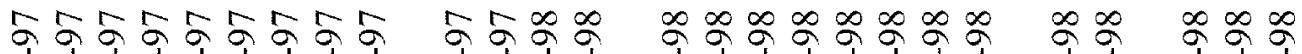

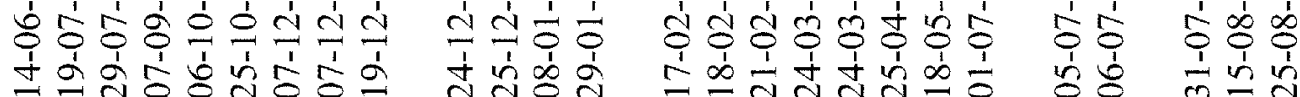

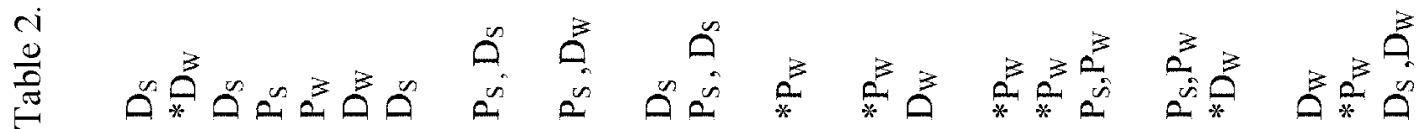

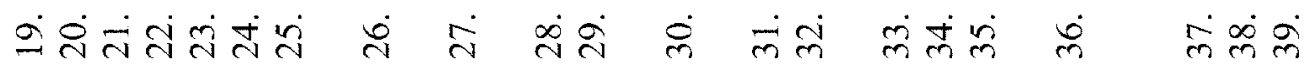




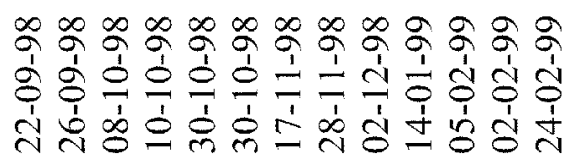

\% g 8 \% 8

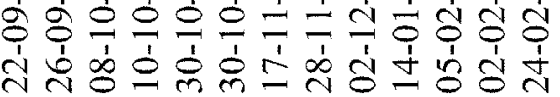

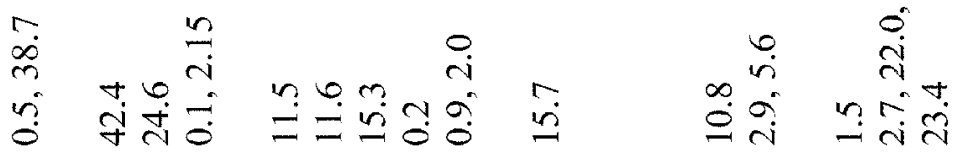

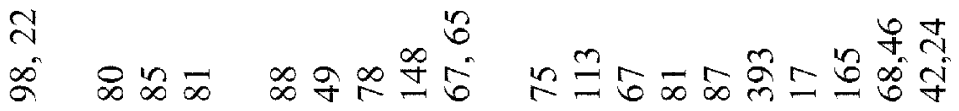

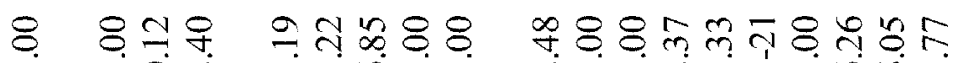

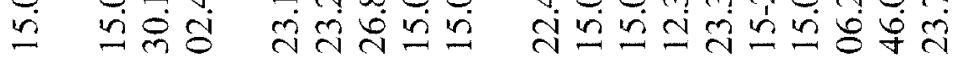

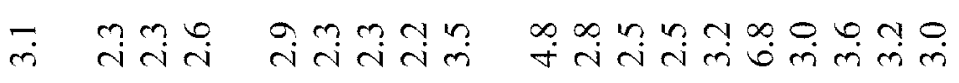

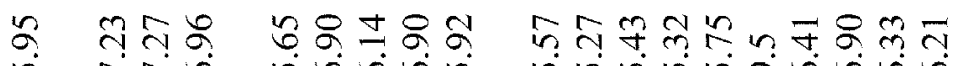

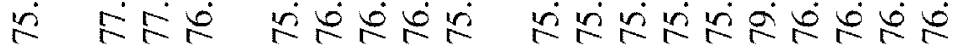

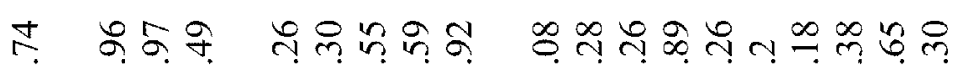

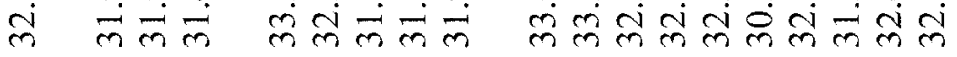




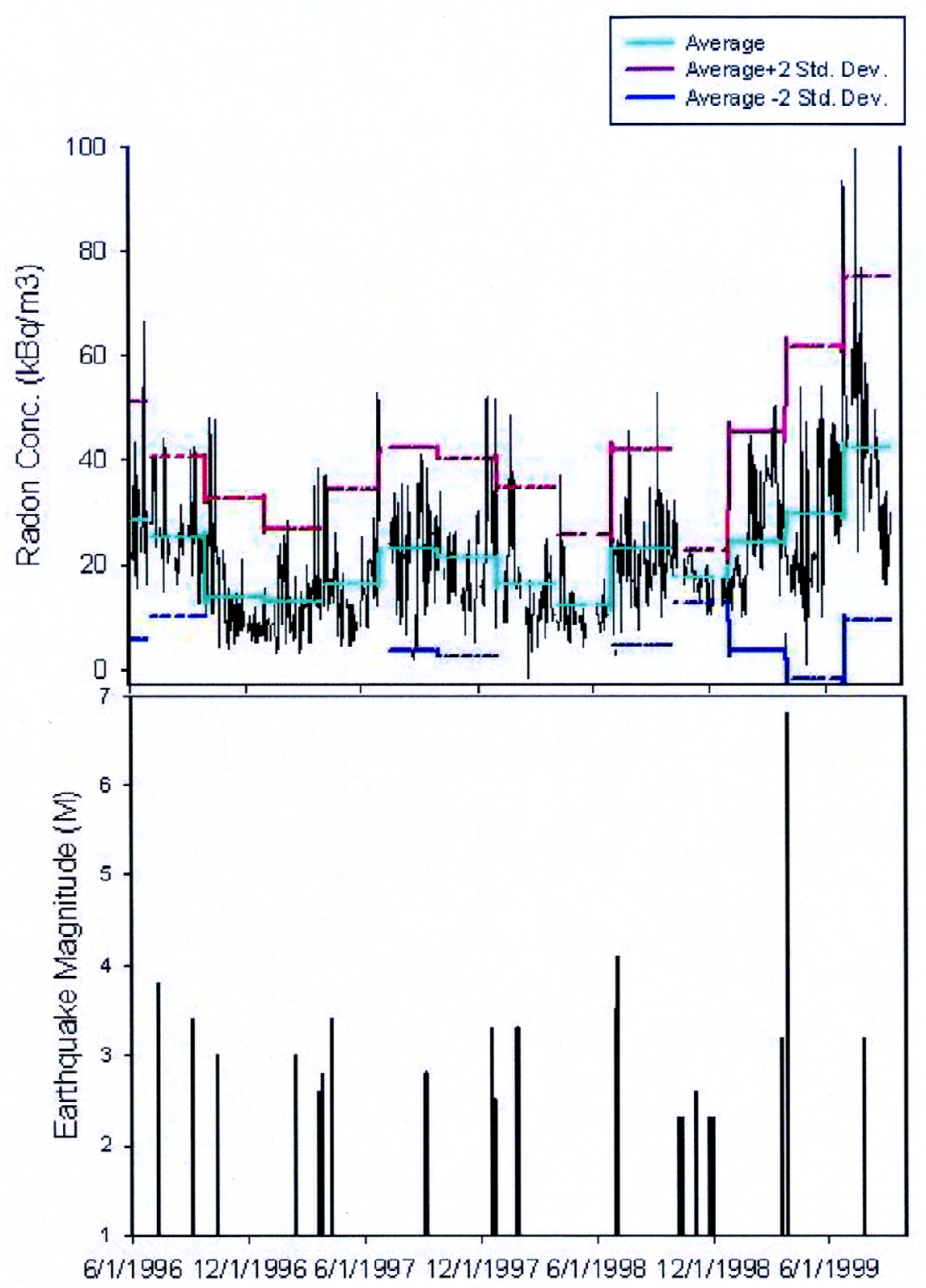

Fig. 7. Radon activity recorded in soil-gas at Palampur along with seismic events correlated with radon anomalies during June 1996 to September 1999. 


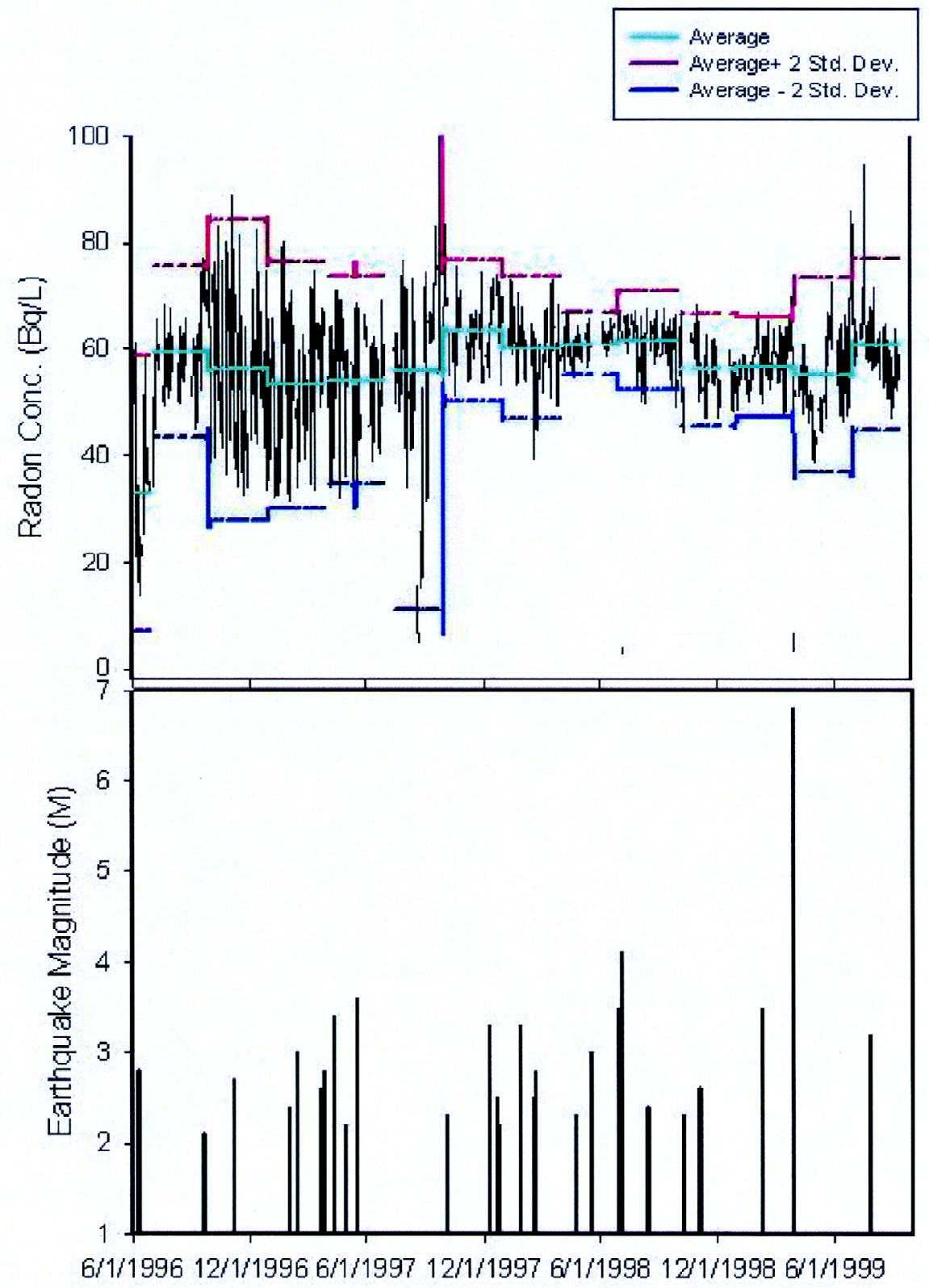

Fig. 8. Radon activity recorded in groundwater at Palampur along with seismic events correlated with radon anomalies during June 1996 to September 1999. 


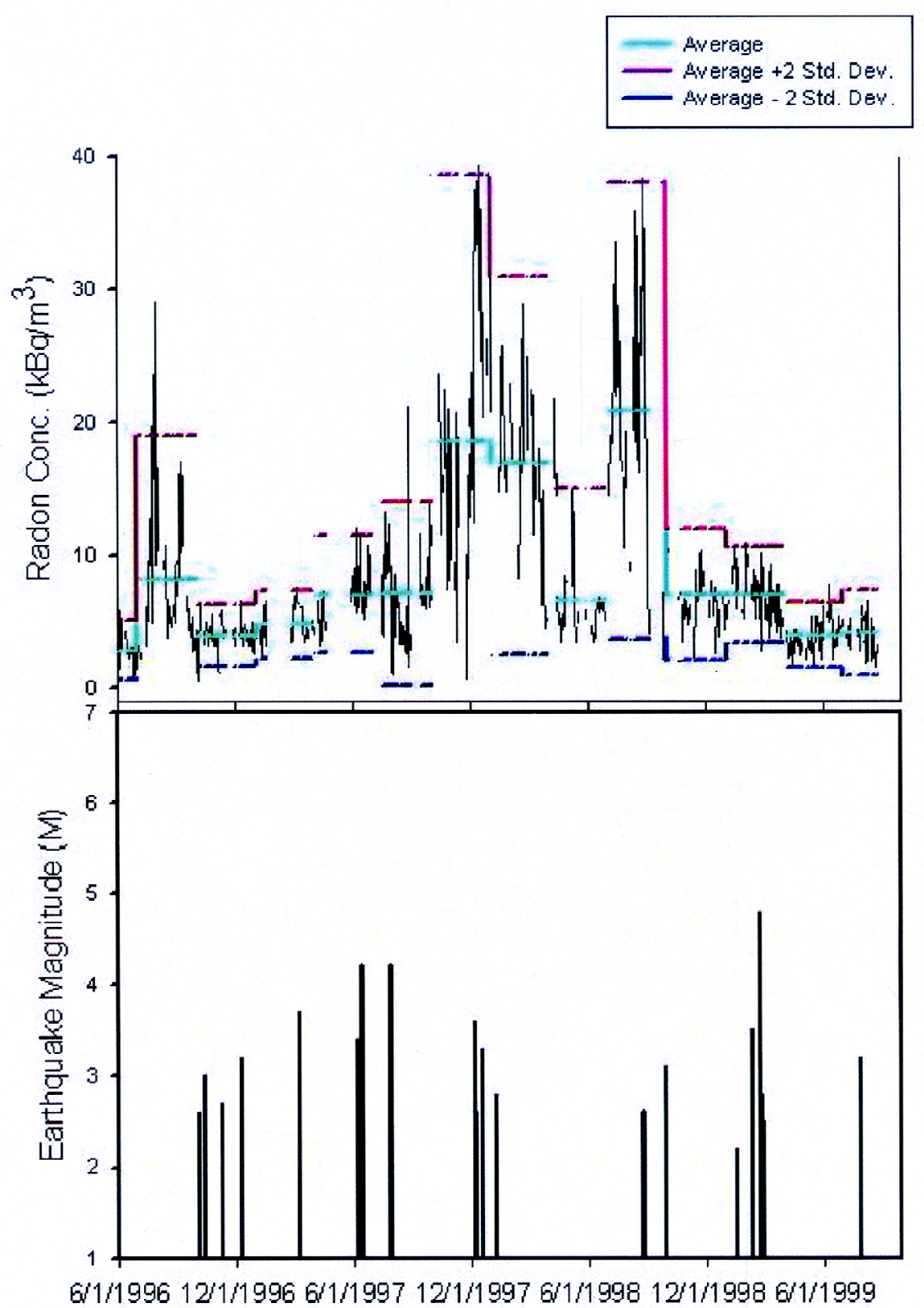

Fig. 9. Radon activity recorded in soil-gas at Dalhousie along with seismic events correlated with radon anomalies during June 1996 to September 1999. 


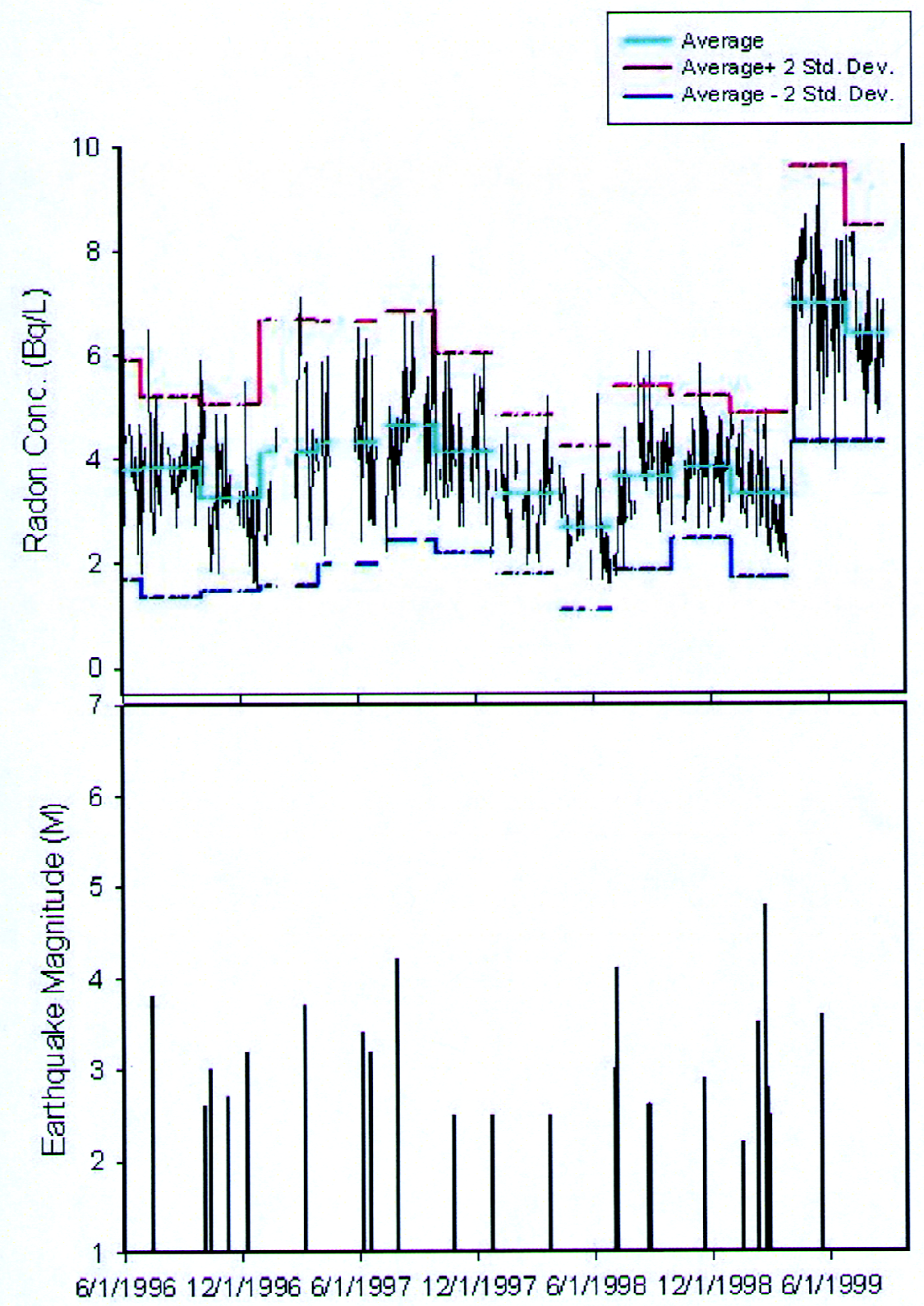

Fig. 10. Radon activity recorded in groundwater at Dalhousie along with seismic events correlated with radon anomalies during June 1996 to September 1999. 
Table 3. Critical analysis of radon anomalies in soil-gas and groundwater.

\begin{tabular}{|c|c|c|c|c|c|c|c|}
\hline Station & & $\begin{array}{l}\text { Total no. } \\
\text { of radon } \\
\text { anomalies } \\
\text { (a) }\end{array}$ & $\begin{array}{l}\text { No. of anomalies } \\
\text { correlated with } \\
\text { events } \\
\text { (b) }\end{array}$ & $\begin{array}{l}\text { No. of anomalies } \\
\text { not correlated } \\
\text { with events } \\
\text { (c) }\end{array}$ & $\begin{array}{c}\text { Signal } \\
(\%) \\
(\mathbf{b} / \mathbf{a})\end{array}$ & $\begin{array}{c}\text { Noise } \\
(\%) \\
(\mathrm{c} / \mathrm{a})\end{array}$ & $\begin{array}{c}\text { Confidence } \\
\text { level } \\
\text { (signal/noise) }\end{array}$ \\
\hline \multirow[t]{2}{*}{ Palampur } & I. Soil-gas & 36 & 21 & 15 & 58 & 42 & 1.38 \\
\hline & II. Water & 26 & 18 & 8 & 69 & 31 & 2.23 \\
\hline \multirow[t]{2}{*}{ Dalhousie } & I. Soil-gas & 29 & 19 & 10 & 66 & 34 & 1.94 \\
\hline & II. Water & 25 & 14 & 11 & 56 & 44 & 1.28 \\
\hline
\end{tabular}

These anomalies occurred when temperatures are lowest in winter, wind velocity is normal, rainfall is scanty and relative humidity normal. The influence of meteorological variables is obvious during July - August 1999, when radon spikes are caused due to heavy rainfall, high relative humidity, high temperatures and low wind velocity. It is estimated that the integrated effect of meteorological variables is less than $2 \sigma$. As a consequence, radon anomalies due to microseismicity can be filtered from the noise generated by meteorological effects. In addition, tidal effects may also influence radon emanation in soil-gas. A comprehensive programme is being worked out to relate radon anomaly amplitude with magnitude and precursor time of earthquakes in N-W Himalaya and to the filter noise from the radon signal.

The following scaling relations have been proposed using the best fit straight line from the log-linear graphs between magnitude of the events (M) and log of the product of amplitude of anomaly (A) and epicentral distance (D) using 142 cases of radon anomalies in soil-gas and groundwater correlated with micro earthquakes in N-W Himalayas (Walia et al. 2003) for the above said time windows of June 1996 - September 1999 and June 1992 - August 1995 (Sharma 1999):

$$
\begin{aligned}
& \log (A D)=0.30 M+3.00,(2.0 \leq M \leq 3.5) \\
& \log (A D)=0.22 M+3.13 .(M>3.5)
\end{aligned}
$$

In the generalised form the above relationship can be written as:

$$
\log (\mathrm{AD})=\mathrm{a} \mathrm{M}+\mathrm{b}
$$

where, 'a' and 'b' are constants. The value of both the constants varies from area to area and depends on local geology and other geophysical factors.

\section{CONCLUSIONS}

From our soil-gas and groundwater radon monitoring results in N-W Himalayas, as well as of other workers reported in the literature, it can be concluded that radon anomalies are generally associated with seismic activity. But the influence of meteorological parameters on 
radon exhalation cannot be neglected. The radon behavior observed in soil-gas and groundwater indicates that the transport phenomenon in soil-gas is entirely different from that in groundwater. Sometimes, we have large increases in radon values in groundwater and at the same time no increase in soil-gas and vice versa. If the transport mechanisms were similar, there should be one to one correspondence between variations of soil-gas and groundwater radon concentrations.

Large-scale variation of anomalies at different monitoring stations suggests that radon anomaly is also dependent on local conditions, i.e., rock type, stress intensity factor, porosity, permeability, carrier gas etc. Radon anomalies are strain indicators in the preparation stage of an earthquake and can be exploited as earthquake precursors for prediction studies. However, the physical mechanism and their relationship with the strain build up are not yet fully understood to propose a comprehensive theoretical model for earthquake prediction. So, presently, anomaly generating models are still largely under debate, although most authors agree in invoking episodic crustal strain/stress field changes as source mechanisms.

From the analysis, it has been inferred that an anomaly is not only influenced by seismic parameters like the magnitude of an earthquake, epicentral distance, precursory time, depth etc., but also by other parameters like meteorological and nature of carrier gases/fluids. Different approaches towards radon's relation with earthquakes draw a picture which shows that there is no consensus on the parameters that may be sensitive to earthquake preparation mechanism or any universal opinion on the mechanisms responsible for radon anomalies. Due to inhomogeneity of the geophysical medium and nonlinearity of the precursor, it is established from the analysis that there is no universal seismo-radon algorithm which holds good for interpretation of radon data for all earthquake magnitudes and epicentral distances. From all the above relationships its can be concluded that till date there has been no model univocally linking earthquakes and radon anomalies, meaning that the validity of the proposed models is not yet proved. So, for having better understanding of the phenomenon involved simultaneous recording of various gases $\left(\mathrm{He}, \mathrm{CO}_{2}, \mathrm{CH}_{4}\right)$ and meteorological parameters, together with multiple continuous measurements of radon has been suggested.

Acknowledgements The authors express their gratitude to Indian Meteorological Department (IMD), New Delhi, India, for supplying the seismic bulletins of IMD network. The senior author/VW is grateful to National Science Council and Central Geological Survey, Taiwan, R.O.C. for providing fellowship to work in Taiwan. The research work was funded by Department of Science and Technology, New Delhi, India, under Himalayan Seismicity Project. Comments and suggestions by two reviewers Dr. V. M. Choubey and Dr. Sebastain Feige were of great help in improving the quality of the manuscript.

\section{REFERENCES}

Anderson, O. L., and P. C. Grew, 1977: Stress corrosion theory of crack propagation with application to geophysics. Rev. Geophys. Space Phys., 15, 77-104. 
Atkinson, B. K., 1979: A fracture mechanics study of subcritical tensile cracking of quartz in wet environment. Pure Appl. Geophys., 117, 1011-1024.

Ball, T. K., R. A. Nicholson, and D. Peachey, 1983: Effects of meteorological variables on certain soil gases used to detect buried ore deposits. Inst. Mining and Metal., Tran., Sec. B, 92, 183-190.

Baranov, V. I., and A. P. Novitskaya, 1960: Humidity effects on emanation (in Russian). Radiokhimiya, 2, 485-490. (in Russian)

Chyi, L. L., T. J. Quick, T. F. Yang, and C. H. Chen, 2005: Soil gas radon spectra and earthquakes. Terr. Atmos. Ocean. Sci., 16, 763-774.

Damkjaer, A., and U. Korsbech, 1985: Measurement of the emanation of radon-222 transport from Danish soils. Scie. Total Environ., 45, 343-350.

Dobrovolsky, I. P., S. I. Zubkov, and V. I. Miachkin, 1979: Estimation of the size of earthquake preparation zones. Pure Appl. Geophys., 117, 1025-1044.

Etiope, G., M. Guerra, and A. Raschi, 2005: Carbon dioxide and radon geohazards over a gasbearing fault in the Siena Graben (Central Italy). Terr. Atmos. Ocean. Sci., 16, 885896.

Etiope, G., and S. Lombardi, 1995: Evidence for radon transport by carrier gas through faulted clays in Italy. J. Radioanalyt. Nucl. Chem., 193, 291-300.

Etiope, G., and G. Martinelli, 2002: Migration of carrier and trace gases in the geosphere: an overview. Phys. Earth Planet. Int., 129, 185-204.

Fleischer , R. L., 1981: Dislocation model for radon response to distant earthquakes. Geophys. Res. Lett., 8, 477-480.

Friedmann, H., 1991: Continuous spring water radon measurement in Austria and possible relations to earthquakes. Inter. Conf. on Earthquake Prediction, Strasbrourg, France.

Gabelman, J. W., 1972: Radon emanometry of Straks Salt Dome Calcasiea Parish, Louisiana. U.S. Energy Commission Rep. RME-414, 75pp.

Gansser, A., 1964: Geology of Himalayas. Interscience, New York.

Ghosh , P. C., and N. S. Bhalla, 1966: A closed-circuit technique for radon measurement in water and soil, with some of its application. Proc. All India Symp. on Radioactivity Metero. Radionuclides, A.E.E.T., Bombay, 226-239.

Hauksson, E., 1981: Radon content of groundwater as an earthquake precursor: Evaluation of worldwide data and physical basis. J. Geophys. Res., 86, 9397-9410.

Hauksson, E., and J. G. Goddard , 1981: Radon earthquake precursor studies in Iceland.J. Geophys. Res., 86, 7037-7054.

Heinicke, J., U. Koch, and G. Martinelli, 1995: $\mathrm{CO}_{2}$ and radon measurements in the Vogtland area (Germany)- a contribution to earthquake prediction research. Geophys. Res. Lett., 22, 771-774.

Hesselbom, A., 1985: Radon in soil gas: A study of methods and instruments for determining radon concentrations in the ground. Uppsala, Sweden. Sveriges Geologiska Undersokning, ser. C., 803, 1-58.

Igarashi, G., S. Sacki, N. Takahata, K. Sumikawa, S. Tasaka, Y. Sasaki, M. Takahashi, and Y. Sano, 1995: Groundwater radon anomaly before the Kobe earthquake in Japan. Science, 269, 60-61. 
Jaacks, J. A., 1984: Meteorological influence upon mercury, radon and helium soil gas emissions. Ph.D. Thesis, Colorado School of Mines.

King, C. Y., 1978: Radon emanation on San Andreas Fault. Nature, 271, 516-519.

King, C. Y., 1986: Gas geochemistry applied to earthquake prediction. An overview. J. Geophys. Res., 91, 12269-12281.

King, C. Y., and A. Minissale, 1994: Seasonal variability of soil-gas radon concentration in central California. Radiat. Meas., 23, 683-692.

King, C., C. Walkingstick, and D. Basler, 1993: Radon in soil gas along active faults in central California. In: Gundersen, C. S., and R. B. Wanty (Eds.), Field studies of radon in rocks, soils and water. U.S. Geol. Sur., 77-143.

Kraner, H. W., G. L. Schroeder, and R. D. Evans, 1964: Measurements of the effects of atmospheric variables on radon-222 flux and soil gas concentration. In: Adams, J. A. S., and W. M. Lower (Eds.), The Natural Radiation and Environment. Univ. Chicago Press, Chicago, 191-215.

Le Fort, P., 1975: Himalayas: the collided range. Present knowledge of the continental arc. Am. J. Sci., 275, 1-44.

Lindmark, A., and B. Rosen, 1985: Radon in soil gas- Exhalation tests and in situ measurements. Sci. Total Environ., 45, 397-404.

Liu, K. K., T. F. Yui, Y. B. Tasi, and T. L. Teng, 1984/85: Variation of radon content in groundwater and possible correlation with seismic activites in the northern Taiwan. Pure Appl. Geophys., 122, 231-244.

Liu, P., D. Wan, and T. Wan, 1975: Studies of forecasting earthquakes in the light of abnormal variations of radon concentration in groundwater. Acta Geophys. Sinica, 18, 279-283.

Miller, J. M., and D. Ostle, 1973: Radon measurements in uranium prospecting. In: Uranium Exploration Methods (Conference Volume). Inter. Atomic Energy Agency, Vienna, 237-247.

Mogro-Campero, A., R. L. Fleischer, and R. S. Likes 1980: Changes in subsurface radon concentration associated with earthquake. J. Geophys. Res., 85, 3053-3057.

Mukherji, P., M. Chatterjee, and K. G. Sen, 2001: Mathematical modelling of radon emanation for earthquake prediction. In: Hunyadi, I., I. Csige, and J. Hakl (Eds.), Proc. 5th Int. Conference on Rare Gas Geochemistry, Ep Systema, Debrecen, Hungary, 27-35.

Narula, P. L., 1992: Neotectonic activity, seismicity and related contemporary deformation in the NW Himalaya. Symp. on Himalayan Geology. Shimate, Japan, 33-36.

Narula, P. L., and S. K. Shome, 1992: Macroseismic studies of recent earthquakes in northwest Himalaya- A Review. Current Sci., 62, 24-33.

Pearson, J. E., 1967: Natural Environmental Radioactivity from Radon-222. Pub. Health Serv. Publ. 999-RH-26. U.S. Dept. of Health, Education and Welfare, Washinton, D.C., 31pp.

Rikitake, T., 1979: Classification of earthquake precursors. Tectonophys., 54, 689-692.

Rikitake, T., 1987: Earthquake precursors in Japan: precursor time and detectabilty. Tectonophys., 136, 265-282.

Sardarov, S. S., 1981: Empirical relationship between anomalies that are short-term predictor of impending earthquakes and earthquake parameters. Dokl. Earth Sci. Sec., 288, 30-34. 
Scholz, C. H., L. R. Sykes, and Y. P. Aggarwal, 1973: Earthquake prediction a physical basis. Science, 181, 803-810.

Seeber, L., and J. G. Armbruster, 1981: Great detachment earthquakes along the Himalayan arc and international review. Am. Geophys. Union, Morris Ewing series., 4, 259-277.

Segovia, N., S. De La Cruz-Reyna, M. Mena, E. Ramos, M. Monnin, and J. L. Seidel, 1989: Radon-in-soil anomaly observed at Los Azufres geothermal field, Michoacan: A possible presursor of the $\left(\mathrm{M}_{\mathrm{S}}=8.1\right)$ Mexico earthquake. Nat. Hazard, 1, 319-329.

Sharma, A. K., 1999: Correlation of radon anomalies with the Microseismicity in the Kangra Valley of Himachal Pradesh India. Ph.D Thesis, Guru Nanak Dev University, Amritsar, India.

Sharma, A. K., V. Walia, and H. S. Virk, 2000: Effect of meteorological parameters on radon emanation. J. Geophys., 21, 47-50.

Singh B., and H. S. Virk, 1994: Investigation of radon-222 in soil-gas as an earthquake precursor. Nucl. Geophys., 8, 185-193.

Singh, M., R. C. Ramola, N. P. Singh, S. Singh, and H. S. Virk, 1988: Influence of meterological parameters on soil gas radon. J. Assoc. Explor. Geophys., 9, 85-90.

Singh, M., M. Kumar, R. K. Jain, and R. P. Chatrath, 1999: Radon in ground water related to seismic events. Radiat. Meas., 30, 465-469.

Steele, S. R., 1981: Radon and hydrologic anomalies on the rough creek fault: Possible precursor to the M 5.1 eastern Kentucky earthquake, 1980. Geophys. Res. Lett., 8, 441444.

Sultankhodzhayev, A. N. 1984: Hydrogeoseismic precursors to earthquakes. Proc. Int. Symp. Earthquake Prediction, UNESCO, Paris 1979, Terra Sci. Publ. Co., Tokyo, 181-191.

Talwani, P., W. S. Moore, and J. Chiang, 1980: Radon anomalies and microearthquakes at Lake Jocassee, South Carolina. J. Geophys. Res., 85, 3079-3088.

Tanner, A. B., 1980: Radon migration in the ground: A supplementary review. Nat. Radia. Environ., 1, 5-57.

Ulomov, V. I., and B. Z. Mavashev, 1967: On forerunner of a strong tectonic earthquake. Dokl. Acad. Sci. USSR, 176, 319-322.

Virk, H. S., 1986: Radon monitoring and earthquake prediction. Proc. Symp. Earthquake Prediction-Present Status. Univ. Poona, Pune, India, 157-162.

Virk, H. S., 1993: Radon and earthquake prediction in India: Present status. Nucl. Tracks \& Radiat. Meas., 22, 483-494.

Virk, H. S., 1996: A critique of empirical scaling relationship between earthquake magnitude, epicentral distance and precursor time for interpretation of radon data.J. Earthquake Prediction Res., 5, 574-583.

Virk H. S., 1997: Radon studies for earthquake prediction. Himalayan Geol., 17, 91-103.

Virk, H. S., and A. K., Sharma, 1997: Micro-seismicity trends in N-W Himalaya using radon signals. In: Virk, H.S. (Ed.), Rare Gas Geochemistry. Proc. 3rd ICRGG held at Amritsar, Dec.10-14, 1995, 117-135.

Virk, H. S., A. K. Sharma, and V. Walia, 1997: Correlation of alpha-logger radon data with microseismicity in N-W Himalaya. Current Sci., 72, 656-663. 
Virk, H. S., and B. Singh, 1992: Correlation of radon anomalies with earthquake in Kangra valley. Nucl. Geophys., 6, 293-300.

Virk, H. S., V. Walia, A. K. Sharma, N. Kumar, and R. Kumar, 2000: Correlation of radon with microseismicity and meteorological parameters in Kangra and Chamba valleys of N-W Himalaya. Geophyis. Inter., 39, 221-227.

Virk, H.S., V. Walia, and N. Kumar, 2001: Radon/helium precursory signals of Chamoli earthquakes, Garhwal Himalaya, India. J. Geodyn., 31, 201-210.

Walia, V., B. S. Bajwa, H. S. Virk, and N. Sharma, 2003: Relationships between seismic parameters and amplitudes of radon anomalies in N-W Himalaya, India.Radiat. Meas., 36, 393-396.

Wedephol, K. H., 1978: Handbook of geochemistry. Springer, Verlag, Berlin.

Yang, T. F., C. Y. Chou, C. H. Chen, L. L. Chyi, and J. H. Jiang, 2003: Exhalation of radon and it carrier gases in SW Taiwan. Radiat. Meas., 36, 425-429.

Yang, T. F., V. Walia, L. L. Chyi, C. C. Fu, C. H. Chen, T. K. Liu, S. R. Song, C. Y. Lee, and M. Lee, 2005: Variations of soil radon and thoron concentrations in a fault zone and prospective earthquakes in SW Taiwan. Radiat. Meas., 40, 496-502. 